\section{DIGITAL COMMONS \\ @ UNIVERSITY OF SOUTH FLORIDA}

\section{ABO: Interactive Journal for Women in the Arts, 1640-1830}

Volume 3

Issue 2 Volume 3.2 (Fall 2013)

Article 2

2013

\title{
Crossing Borders: An Interdisciplinary Course in the "Enlightenment"
}

\author{
Carol White \\ Clayton State University, carolwhite@clayton.edu \\ Kathryn P. Russell \\ Clayton State University, kathrynprattrussell@clayton.edu
}

Follow this and additional works at: https://digitalcommons.usf.edu/abo

Part of the Dramatic Literature, Criticism and Theory Commons, Educational Methods Commons, Feminist, Gender, and Sexuality Studies Commons, and the Literature in English, British Isles Commons

\section{Recommended Citation}

White, Carol and Russell, Kathryn P. (2013) "Crossing Borders: An Interdisciplinary Course in the "Enlightenment"," ABO: Interactive Journal for Women in the Arts, 1640-1830: Vol.3: Iss.2, Article 2. http://dx.doi.org/10.5038/2157-7129.3.2.2

Available at: https://digitalcommons.usf.edu/abo/vol3/iss2/2

This Pedagogy is brought to you for free and open access by Digital Commons @ University of South Florida. It has been accepted for inclusion in ABO: Interactive Journal for Women in the Arts, 1640-1830 by an authorized administrator of Digital Commons @ University of South Florida. For more information, please contact digitalcommons@usf.edu. 


\title{
Crossing Borders: An Interdisciplinary Course in the "Enlightenment"
}

\begin{abstract}
In this essay, we present a twofold version of the first team-taught course on the eighteenth century designed by faculty at Clayton State University who plan to develop and teach this course again in the near future. We hope that our explanation of the original course and our projected future version of the course will be useful to scholars who teach in the eighteenth century, as well as to specialists in other historical periods who wish to plan revisions of courses to make them more reflective of current scholarship in gender studies. Authors taught in this course include Benjamin Franklin, Voltaire, Denis Diderot, Helen Maria Williams, and others.
\end{abstract}

\section{Keywords}

Enlightenment, Franklin, Voltaire, Diderot, Helen Maria Williams, Burke

\section{Creative Commons License}

(c) (1) $\Theta$

This work is licensed under a Creative Commons Attribution-No Derivative Works 3.0 License. 
In this essay, we present a twofold version of the first team-taught course on the eighteenth century designed by faculty at Clayton State University who plan to develop and teach this course again in the near future. We hope that our explanation of the original course and our projected future version of the course will be useful to scholars who teach in the eighteenth century, as well as to specialists in other historical periods who wish to plan revisions of courses to make them more reflective of current scholarship in gender studies.

Carol White, from History, and Kathryn Pratt Russell, from English, originally taught this course with two other professors: Adam Tate, a specialist in American history, and E. Joe Johnson, who publishes on French literature and culture. For Fall of 2011, the four of us put together a course that asked students at the sophomore and junior levels enrolled in the Honors Program to engage in sustained, seminar-style discussion of major texts from eighteenth-century Europe and America. As we introduced them to some of the most influential political and literary writers of modernity, we made sure that they were familiarized with the cultural backgrounds and content of the "Enlightenment" through introductory lectures and conversations. Our initial agenda for the course was to help students understand that one prominent goal of Enlightenment writers was to reform society for the better. However, we learned from teaching the course that trying to use such a broad "reformist" brush to paint the entire Enlightenment as it took shape across Europe and America resulted in a rather messy picture for the students. "To reform society for the better" might have been the goal of many eighteenth-century thinkers, but without a more focused theme, we risked imparting little more to the students than a cliché about the eighteenthcentury social contract and the progress in human rights.

In teaching this course, we learned that interdisciplinary teaching requires a great deal of planning by the team of professors, so that broader context and nuanced readings work together to bring the student a coherent and assimilable course. In our evaluation of the course, we realized that the topics of women and gender, which had been addressed in the first iteration, had often given us the purchase we needed to have students begin to understand the complexity of the Enlightenment beyond facile notions of progress and liberty. For this reason, our revision of the course will focus closely on Enlightenment definitions of freedom and agency, with special attention drawn to how these concepts were applied to (or denied to) women.

Why would a course in the "Enlightenment" have particular resonance as the first team-taught course to be offered by the Honors program? Clayton State's very existence could be said to be both a testament to the American support of the "Enlightenment" project, and a critique of the oppressive social structures that even Enlightenment thinkers had trouble reimagining, for example the inadequate access of the poor to equal opportunity. Clayton State University's teaching mission is especially geared toward helping minority and non-traditional college students in their efforts to learn and to gain credentials that will serve them well in the working world. Clayton State serves 7,000 students, 68\% of which are African-American, 24\% EuropeanAmerican, and $8 \%$ of other ethnic backgrounds. More than $60 \%$ of our student population gains access to higher learning through Pell Grants, and about $80 \%$ of our students receive some form of federal financial aid. We are proud to say that in the past seven years, the number of degrees we have awarded to African-American students has increased by $92 \%$, and the number of degrees awarded to Pell grant recipients increased by $118 \%$. In this course on the 
"Enlightenment," we hoped to show our students how relevant eighteenth-century writers can be to an informed understanding of our own positions as American and global citizens.

We developed the seminar specifically for the Honors Program. Enrollment in the program is based solely on SAT or ACT test scores, not past performance. Like many of the students at Clayton State, those in the Honors Program often have modest educational backgrounds. They are highly motivated, but not necessarily better prepared for close readings of Enlightenment texts. Moreover, there are typically very few liberal arts majors in the program; most students are pre-med or nursing majors. The challenge in developing the course for this group was to tap into the motivation of the students and to give them some control over the direction of the class, while nonetheless providing sufficient guidance so that they did not feel overwhelmed or incapable. To that end, professors offered introductory lectures for each text, which provided cultural and historical context and introduced some of the main themes that would be addressed for that text. Once the reading of the text began, however, more control was gradually handed over to the students. For each class meeting, three to five discussion questions were circulated in advance. The professor typically provided the first set of questions, but student volunteers offered subsequent sets. Although not every question provided by the students advanced the learning process, the professors were always on hand to expand or gently direct the discussion into richer territory.

The team-taught format provided for a transnational approach to the Enlightenment, which allowed students to explore the impact of context on the development and implications of Enlightenment ideas. The interdisciplinary format also enabled a breadth of perspectives and approaches. Tate, Johnson and Pratt Russell share a focus on "text and meaning" while White brings particular attention to how the ideas of the Enlightenment were shaped by social context and personal relations among Enlightenment writers. It is worth noting that Johnson, Pratt Russell and White all have backgrounds in gender studies and brought those approaches to their respective sections. The interdisciplinary nature of the class, to some extent, supplemented the goal of the university's core curriculum - to offer a basic foundation on which students can build their educational goals. The class moves beyond the core, however; its more rigorous approach requires students to engage in sustained, deep thinking. Given that most of the students in the Honors Program are not liberal arts majors, the course played an essential role in rounding out the educational experiences of the students in the program.

Adam Tate was the instructor of record for the course and the only faculty member who participated in every class meeting. The remaining three faculty members were each responsible for three weeks of the course. When schedules allowed, faculty members sat in on classes led by the other members of the faculty and participated in discussion. Each section of the course ended with a short paper. The paper prompt was provided by the instructor, but to ensure continuity for the students, Tate graded all the papers.

\section{Course Overview}

The first text for the class, The Autobiography of Benjamin Franklin, was taught by Adam Tate, who is an intellectual historian of the American Revolutionary and Antebellum periods. He has a particular interest in early America's shifting notions of such core ideas as republicanism and rights. Tate showed the students how Franklin's Autobiography exhibited many of the key ideas 
presented in the introductory lecture on the Enlightenment, most notably the importance of the empirical method and the desire to redefine religion in order to achieve more intellectual freedom in society.

Joe Johnson led the discussion of the next text, Candide. Johnson's research is not limited to the Enlightenment, but extends back to the seventeenth century. His work on the French Enlightenment focuses on both canonical and popular texts and is informed by gender studies. The examination of Candide began for the students the rigorous process of destabilizing the established narrative of the Enlightenment. Voltaire turned his sharp wit on many of the expected targets, but he also interjected doubts about the applicability of the empirical method to human experience.

Carol White led the next section, selections from the Encyclopédie. White's research focuses on the French Enlightenment as a community, examining the interactions of the members of that community and their collaborative endeavors. Her selections from the Encyclopédie enabled sustained discussion of the issue of women. Through the comparison of the articles, students were guided into noting the contradictory treatments of women's nature and social function.

Kathryn Pratt Russell shifted focus to the British perspective, particularly Romantic literature and culture. Pratt Russell specializes in the rhetoric of Romantic emotions, as well as in the material culture of the long eighteenth century in Britain. In the original course, Pratt Russell taught Edmund Burke as a writer of sensibility, showing how he used feeling to criticize the philosophes' dry, "inhumane" reasoning, and to portray them as "cultish plotters." His example demonstrates that Enlightenment writers varied in their methodology, reasoning, and ultimate goals.

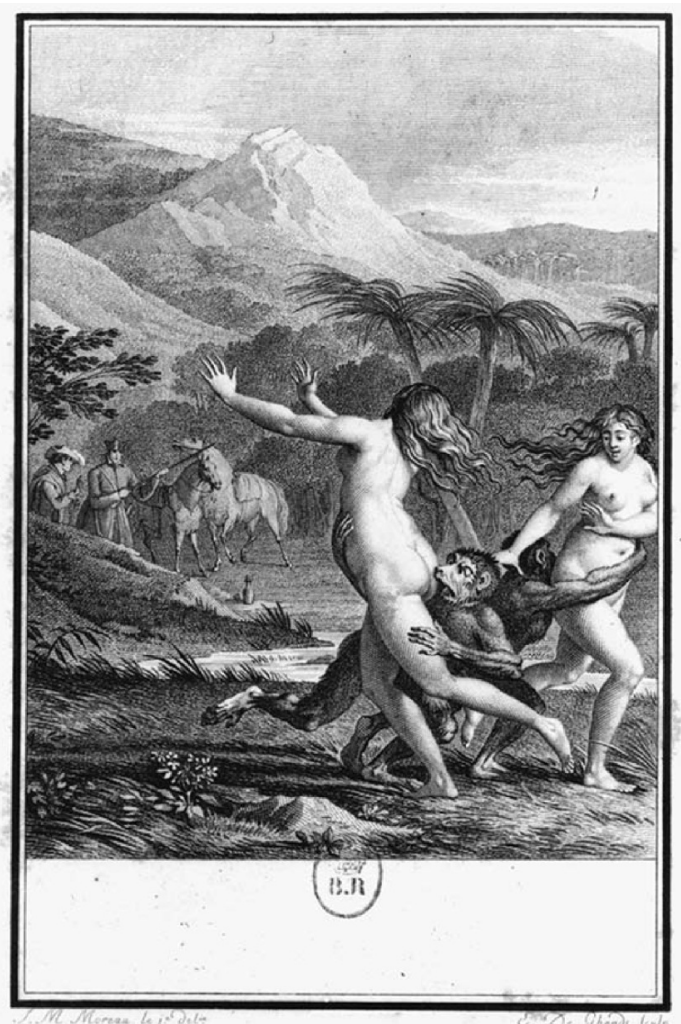

"The two wanderers heard a few little cries" 


\section{Texts and Details}

\section{Autobiography of Benjamin Franklin}

\section{Fall 2011}

Following Carol White's introduction to the Enlightenment as a tradition through which narratives of modernity have been organized, historian Adam Tate began the course with the Autobiography of Benjamin Franklin. Tate made a compelling case for the view that Franklin presented himself as the "natural man" of Enlightenment reason, depending not on an elite education, but on self-discipline, selfimprovement, and practical morality. Tate began the series of small-group discussions that would structure the entire course, and he encouraged students to turn in discussion questions that they had developed from the readings and the lectures. Thus, the students themselves had a shaping hand in the development of the course, and their interests and their interpretations of the texts were important (Fig 1). As the students explored the Autobiography, we provided important information for them on the religious context of Franklin's early life in Boston and Philadelphia, and how Franklin crafted his philosophy of optimism in opposition to Puritan-influenced Christian theologies of humanity's innate sinfulness and need for reliance upon divine grace, not upon one's own efforts at selfimprovement or goodness. Tate also emphasized Franklin's complicated political journey from British royalist to American revolutionary. In delving deeply into Franklin's representation of his own self-making and politicking, we helped the students to see how Franklin's autobiography presents an argument for how the "modern" Enlightenment man should function as both critic of and contributor to his society. Although Franklin has been seen by many historians as the quintessential American "Founding Father," this section of the course gave students the larger, border-crossing view of Franklin as a man who saw himself as British, and American, and a friend even to the French in their quest for progress.

\section{Fig. 1. Discussion Questions on Benjamin Franklin by Michael Ngo (Student)}

1. Benjamin Franklin developed a unique way of reasoning as he matured in his autobiography. As with the eating of fish while being on a vegetarian diet, Franklin's use of reasoning convinced him to be a thorough Deist as well as making him conclude that his character was proper and didn't need religion (pages 63 and 64). Why do you think it was important for Benjamin Franklin to pause and note this to his son? Is his way of thinking reasonable? Why or why not? Find examples.

2. After a close call with the financial situation with the merchant, Benjamin Franklin seems to blow into yet another wind of success. From page 71 to 73 , Benjamin cuts off all the partnerships with his business and is helped by his friends to pay his debt. Benjamin also receives a job to print money and slowly begins to pay back his other debts. Do his credentials seem to single him out to be the only person fit for the job of printing money, or was he simply at the right place at the right time? In what ways did meeting the Catholic Maiden help him through this?

3. The topic of marriage has popped up more than once in my reading. On pages 74 and 75 , Mrs. Godfrey proposes a match with her daughter, and on page 76 , he thinks of marrying Mrs. Read, which he ends up doing. In one marriage, he wants to use the bond to pay off his debts, but in the other, he is prepared to assume the debts. What was Franklin's reasoning behind his marital choices? Was he trying to get some fortune or good luck through the marriage, or was he genuinely serious about the marriage? 


\section{Revision}

We will incorporate many elements of the first version of the Franklin section, but we are also interested in adding a literary approach to the Autobiography. We will ask students to consider Franklin's goals in crafting for readers a version of himself in which some early experiences (theatergoing in London, for instance) were downplayed, and mentioned in his Autobiography only as the early follies that allowed the building of his philosophy of optimism and hard work. We will incorporate in our lectures some material from recent Franklin biographies- including Walter Isaacson's Benjamin Franklin: An American Life (2003) and Edwin Gaustad's Benjamin Franklin (2006) - in order to see how they offer a version of Franklin's life that is fuller and richer, but less coherent in terms of establishing a template for the self-made "Enlightenment" man. Moving to the biographical facts behind the myth, we will explore Franklin's wife Deborah Reade Franklin as the unsung hero of Franklin's career. In the Autobiography he says only these words of her work for him, "she proved a good and faithful helpmate, assisted me much by attending the shop; we throve together, and have ever mutually endeavored to make each other happy" (71). Yet Deborah lived apart from Franklin for eighteen years and ran his shop and other business endeavors. We will turn to material from Eugenia Herbert's The Private Franklin: The Man and His Family so that we can restore some balance to an account of Franklin's work with his major business partner: his wife. We will also examine Franklin's famous "Silence Dogood" letters, in order to analyze Franklin's motives for constructing a middle-aged female persona for his publishing debut at sixteen. Reading these letters will allow us to consider the question of the possibilities for and limits of women's authority, in this case as a young male writer imagines it, in the eighteenth century.

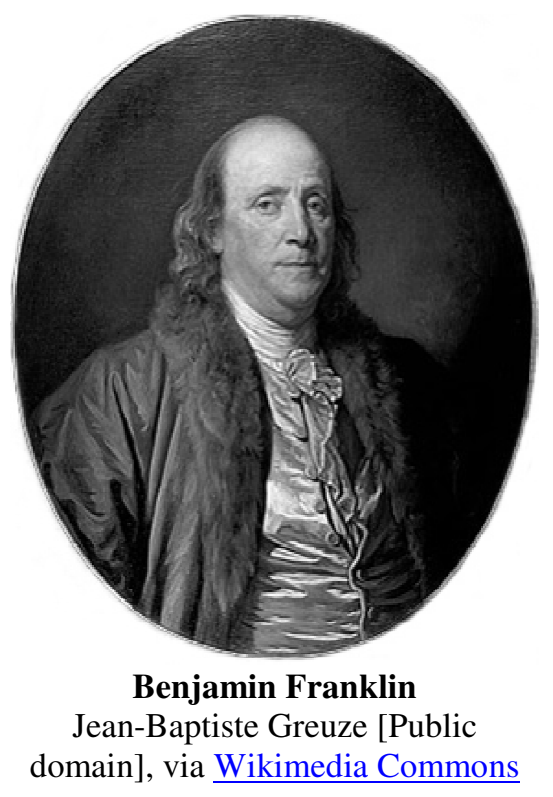




\section{Candide, Or Optimism}

\section{Fall 2011}

E. Joe Johnson chose Voltaire's Candide to introduce students to the French variation of the Enlightenment. To facilitate their reading of the text, he provided students with important background information on Voltaire's life and historical events referenced in the novel. Students also received an introduction to key concepts like satire, irony, deism, and optimistic determinism. Students read four to five chapters for each class meeting. Since the novel was not read in its entirety from the start, discussion tended to wander, just as the characters in the book wandered the world. This approach meant that some topics only received brief attention as they appeared in the novel. For example, the first discussion focused on Voltaire's satire of the German nobility. This topic received little attention in the rest of the novel, so it was not necessary to return to the issue in any depth in later class discussions.

Given this approach, it sometimes took several classes before major themes or concepts emerged. Nonetheless, two issues proved recurring and received significant attention. The first was Voltaire's criticism of religion. Numerous episodes, such as Candide's early experiences in Holland and his encounter with an enslaved African in Surinam, used irony to point out the apparent hypocrisy in the practice of eighteenth-century Christianity. Discussion questions did not explicitly make comparisons between similar events in the text. Instead, Johnson relied on the students to make the necessary connections on their own during the course of discussion, which they were generally successful in doing. The earlier introduction to the concept of deism facilitated the discussion of religion in the novel. Students quickly acknowledged that Voltaire's main criticism of religion was not about faith in God, but rather the way in which humans distorted religion for their own purposes.

The second major theme that received attention was the debate in the novel over the cause of evil in the world. The topic is an obvious one given Pangloss's optimism and the numerous assaults to that philosophy that Candide encountered during the course of his voyages. But one episode in particular proved fruitful for discussion. After hearing the tale of the Old Woman, Candide lamented that Pangloss was no longer alive to provide insight into nature of physical evil (created by nature) and moral evil (created by the actions of humans). In discussion, we asked 
students to compare physical to moral evil and relate the distinction between the two to the philosophy of optimism. Whenever characters in the novel experienced misery or sorrow, we asked students to identify if the source of the tragedy was physical or moral (Fig. 2) At the end of the semester, students wrote a final paper on the topic, identifying which Voltaire believed was the main source of evil. Johnson also asked students to reflect on the ending of the novel and how it may represent Voltaire's solution to the problem of evil (Fig. 3).

Fig. 3. Essay Prompt for Voltaire's Candide by Dr. E. Joe Johnson

On page 32, at the end of the first paragraph of chapter 32, Candide expresses his regret that Pangloss is not there to deliver a "remarkable lecture on the physical and moral evil that holds sway over land and sea." We can take "physical evil" to mean things like natural disaster, and "moral evil" as what is caused by humankind.

In your 3-page (double-spaced, 12 point font, 1inch margins) essay, explore the various causes of both kinds of evil in Candide, giving specific examples from the reading. On the basis of these examples, determine which one of the two evils is the predominant source of violence in the text and whether or not Voltaire provides any response for them at the conclusion of the novel.

\section{Revision}

Women and gender did not feature prominently in the discussion of Candide in the first iteration of the course. Admittedly, before reading the selections from the Encyclopédie, students do not have much theoretical background to make sense of the gender issues in the novel. Nonetheless, students independently demonstrated interest in topics about women and gender. For example, one student posed the following question for discussion: "The Old Woman advises Cunégonde to marry the Governor, while Candide begs His Excellency to grant his marriage to Cunégonde. Do you think it would be a better choice for Cunégonde to marry the Governor or to flee with Candide? And why?" By pitting practicality (the Governor) against romance (Candide), this question potentially broaches the topic of the disparity between the lives of men and women in the Enlightenment era. The female characters had fewer opportunities and different challenges compared to their male counterparts. Although Candide is often read as a fantastical novel, these differences reflect the real horizons of eighteenth-century men and women. We will encourage students to discuss these differences and consider what they may tell us about gender roles in the eighteenth century.

Another topic that will receive greater attention in the future is the prevalence of sexual coercion in Candide. One of the recurring tropes in the novel is the telling of personal stories of tragedy. The Old Woman challenges anyone to tell a story more sorrowful than her own, while Candide selects a travel companion based on who has the greatest tale of woe. Sexual vulnerability and violence is a common thread in the stories told by the female characters. A discussion of the sexual violence that the women in the novel feared or experienced can easily dovetail into the existing discussion about the causes of evil, serving as an example of moral evil. But the intention is to expand the discussion, asking students to think about why Voltaire focused on sexual vulnerability specifically for his female characters. Why does it appear to convey tragedy so effectively for women? What does it tell us about representations of women in the eighteenth century? It is not necessary for students to have definitive answers for such questions at this point in the course. Instead, merely focusing students' attention on the issue prepares them for the next section on the Encyclopédie, which takes up questions regarding representations of women and sexuality in greater detail. 


\section{Selections from the Encyclopédie}

\section{Fall 2011}

Carol L. White divided the selections from the Encyclopédie into two main sections (Fig. 4). The first section focused largely on religion. Compared to Candide and its heavy use of irony and satire, the Encylopédie articles are relatively straightforward with arguments about religion that address three main issues: how religion became corrupted, the repercussions of this corruption for society, and how best to correct the situation. We directed students to identify the different approaches that the authors used in addressing their subjects, most of which were examples of Enlightenment empiricism. At the end of the section, we had students imagine what kind of religion and church the authors of the Encyclopédie would have established. This exercise reminded students that, at its heart, the Enlightenment was a reform movement. It was not enough for Enlightenment writers to criticize their society; the ultimate goal was to reform society for the better.

Fig. 4. List of articles from the Encyclopédie by
Dr. Carol L. White
Articles on Religion
Day One: Natural Rights, Tolerance, and
Intolerance
Day Two: Intolerant Man, Fanaticism, Prejudice,
Inquisition, and Jew
Day Three: Worship, Priests, Cowl, Grey Friars,
and Geneva
Articles on Women, Gender, and Sexuality
Day One: Woman (Anthropology, Ethics and
Jurisprudence) and Female Sex
Day Two: Modesty (Pudeur, not Modestie),
Virginity, Lesbian, and Sodomy
Day Three: Marriage (Jurisprudence and
Theology), Wife, and Adultery

This focus on reform was critical for the second section, which centered on issues of women, gender, and sexuality. Through the comparison of the articles, White helped students note the ambiguous treatment of women. For example, in the article "Woman" (Ethics), the author emphasized the possibility of education to alleviate the inferior status of women and improve their circumstances. Nonetheless, the same article frequently referred to inherent and unalterable natural characteristics of women. This discourse of nature is a major challenge to the established narrative for our class of Enlightenment empiricism. Although this discourse does mesh with the empirical method, insomuch as the goal of the scientific method was to identify the immutable laws of nature, it is not in line with the Enlightenment goal of reform. Locked into roles defined by nature, it would seem that women - and by consequence their role in society-were beyond the reach of reform. Discussion focused on the possibility of extending Enlightenment reforms to the lives of women.

At this point, students were beginning to view the Enlightenment more critically. Specifically, this discussion of women raises the question of what was the real motor driving the Enlightenment: its empirical method or its reform agenda? Moreover, was this reform agenda clearly delineated? The article "Wife" proved telling. A student provided the discussion questions for that day, and her question for the article focused on the Enlightenment vision of women's roles and the possibility of gender equality (Fig. 5). To address the question, we examined how the author of the article "Wife" argued that a woman's subordination was a matter of circumstance and not a law of nature. This argument, we noted, seemed to open the door to the possibility of altering traditional gender roles, a goal in line with the Enlightenment project of social reform. But further in the article, the author argued that a woman became subordinate to her husband when she consented to marriage. In this way, the author appeared to shut the very 
door that the article had just opened. We did not attempt to resolve this type of ambiguity in class discussion. Instead, students realized that although there did seem to be some interest in reforming gender relations, there appeared to be greater hesitancy compared to other areas of reform, such as religion and government.

Fig. 5. Discussion Questions on the Encyclopédie by Nuzhat Momin (Student)

1. What are some of the ways in which the article "Wife (Natural Law)" opposes the "Woman (Anthropology)" article in relation to a woman's role in society? Do the Enlightenment writers believe in a patriarchal society or one in which both sides have equality?

2. In the last line of the first paragraph of the article "Adultery (Ethics)," the author poses a question concerning what type of adultery is most harmful to society. Does he answer the question in the article? Note: The author refers to males in the question.

3. On page 3 of the article "Marriage (Jurisprudence)" and at the end of page 2 of the article "Adultery (Ethics)," the authors discuss celibacy. Are the Enlightenment authors against celibacy or for it? Are they once again using a double entendre to speak against the Church?

\section{Revision}

In the original version of the course, the class then examined readings on Africa and the Americas and traced ambiguities and inconsistencies similar to those in the articles on women, gender, and sexuality. In the future, White will replace this section with Jean-Jacques Rousseau's Letter to d'Alembert and Mme. de Staël's response to the letter in her Letters on the Works and Character of J.J. Rousseau. Rousseau's letter fits nicely in the discussion on the Encyclopédie because it was Rousseau's response to d'Almbert's article on Geneva, which the students read. We will initially position the Letter as a work of opposition to the Encyclopédie and its understanding of the Enlightenment. We will note that not only did its publication mark Rousseau's public break from the Encyclopedists, but also that many of the ideas in the Letter oppose the core principles of the Enlightenment as already presented in our course.

By drawing attention to Rousseau's criticisms of d'Alembert's article and its assumptions, for the first time in the course we are exploring the reactions against the Enlightenment. The development of a critical response to the Enlightenment will take center stage in the next section on Edmund Burke and the language of sensibility. Indeed, many of Rousseau's ideas anticipate some of the concerns to be addressed in the subsequent section. For example, in his discussion of the experience of watching theatrical performances, Rousseau expressed fear over igniting excessive emotion. Concern in the eighteenth century over excessive feeling and its consequences is one of the topics addressed in the succeeding section.

The Letter to d'Alembert also deepens the discussion of the reform agenda of the Enlightenment. The central issue of the letter is the role that theater, and the arts more generally, can play in the formation of good social mores. D'Alembert argued in favor of using the theater as an instrument of education and social reform, but Rousseau rejected the possibility. Most importantly, whereas the articles from the Encyclopédie were ambiguous in considering gender relations as part of their social reform, Rousseau placed these relations at the center of his project. Rousseau argues that properly ordered gender relations are essential to a well-functioning society. Class discussion will focus on the issues of social reform, Rousseau's vision of proper gender relations, and a comparison between his ideas about women's roles and those presented in the Encyclopédie. This comparison should reveal that Rousseau's ideas about women's role in society were, in many cases, remarkably similar to those found in the Encyclopédie. In particular, 
Rousseau's discussion of the virtues of female modesty strongly echoes the Encyclopédie's entry on the subject. We will end by discussing the implications of such similarities and what they mean for women by turning to Mme. de Staël's discussion of Rousseau's letter. Staël's response is worthy of examination because, although she tries to defend women's active engagement in public life, she embraces many of Rousseau's characterizations of women's nature. This ambivalence in Staël's writing allows for exploration of the legacy of Enlightenment notions of gender from the perspective of women.

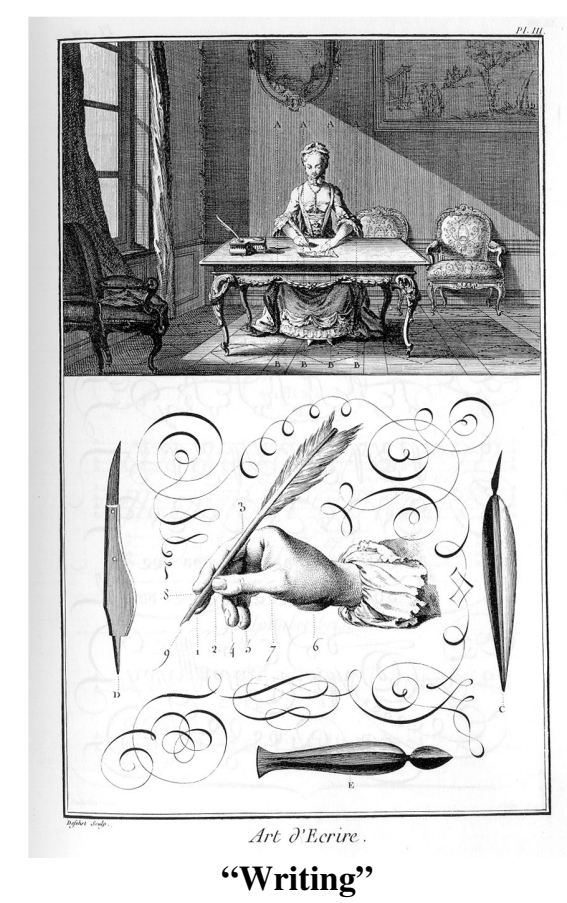

Plate III [Public domain], via ARTFL Project 
Edmund Burke, Sensibility, and Helen Maria Williams

\section{Fall 2011}

Kathryn Pratt Russell began this section of the course by asking students to read the first seventy pages of Burke's Reflections, and to discuss in class the connections between Burke's theories of good government and the ways we think about good or appropriate government in the United States today. We included a list of current Congressional representatives and their educational and career backgrounds, in order to help students make comparisons between Burke's position as a member of Parliament and unapologetic elitist, and positions of the current U.S. representatives with their more varied academic and career credentials.

After this session, we turned immediately to Thomas Gray's mid-century sentimental classic, "Elegy Written in a Country Church-Yard," to show what kinds of emotional language were valued by readers in the eighteenth century. The students found this introduction to poetry jarring, to say the least, and they struggled to understand what the connection could be between Burke's Reflections, written in the voice of a man of moderation and good sense, and Gray's "Elegy," written in a tone of sympathy so extreme that twenty-first century readers can find it mawkish, or at least overwrought. Our students began to realize that this section of the course was about how "reason" perceived "feeling" in the eighteenth century when we returned to our reading in Reflections. This time, we asked ourselves how Burke was using the language of sensibility that we had seen in Gray. The students started to realize that Burke's "moderate" political position is built upon his depiction of an ideally reasonable "natural" emotion, as opposed to hysterical, overwrought revolutionary passion.

When we reached William Cowper's poetry of the 1780s, students could see that emotion and its excesses were a central concern for the period during which Cowper and Burke wrote. Examining excerpts from Cowper's “The Winter's Evening” in The Task, we talked about how Cowper and other thinkers of the day viewed the "instant news" of the modernizing postal system as potentially emotionally excessive, and how Cowper's domestic retreat allows him to view the passionate goings-on of London from a reasonable and moderate distance. We then read selections from Wordsworth in order to see how "excessive" feeling became something not to be fled from, but to be tamed and shaped into imaginative power by the Wordsworthian imagination.

Finally, while we completed the last readings in Reflections, we perused excerpts of Lord Byron's Childe Harold's Pilgrimage, in order to complete our exploration of the eighteenthcentury literature of feeling by looking at what happened to "excessive" feeling when it was represented as a positive social force by popular poets of the early nineteenth century. With this wrap-up of the course section, students became more comfortable with the idea that Burke's theories of government do not represent a monolithic and unique creation, but instead a blending and transforming of the battle over the proper relation of reason (or "Enlightened" reason) and feeling in eighteenth-century society (Fig. 6). 


\section{Fig. 6. Excerpt from Student Paper on Edmund Burke's Reflections by Skyler Keeton November 8, 2011}

Burke and the Language of Sensibility

Not only does Burke use sensibility to try and change the revolutionaries, but he also uses it to create his vision of a morally justifiable political order. He does this by using words that evoke feelings in the readers and by falling back on the Age of Sentiment concept that feeling unites all.

Edmund Burke was a skilled writer, and he was very good with words, so writing something that would manipulate feelings in his readers would be a very simple thing to do. Indeed, while reading this book, his contemporaries would probably feel angry the whole time. Burke believes that in his morally justifiable political order, all of the people that are in charge would be in charge because they were born and educated to do so. He mentions this belief briefly on page 74 when he is describing the queen in her imprisonment, and how she deals with it "in a manner suited to her rank and race, and becoming the offspring of a sovereign distinguished for her piety and her courage." Emotional words he uses in this sentence are "piety" and "courage". The reader is made to feel sorry for Queen MarieAntoinette because she is imprisoned, even though her actions landed her there in the first place. In Burke's political dream, there would be order because everyone would know her place and be educated in that field so that she could better serve her country.

Bibliography

Burke, Edmund. Reflections on the Revolution in France. Mineola, NY: Dover Publications, 2006. Print.

culture of sensibility in all of its threatening excess. We will also read excerpts from G. J. Barker-Benfield's The Culture of Sensibility: Sex and Society in Eighteenth-Century Britain (1996), which makes a compelling argument that the struggle to define gender roles within the

\section{Revision}

Instead of comparing and contrasting Burke's Reflections with Thomas Paine's writings, as we did the first time around, we plan to further explore the complications of the "culture of sensibility" of the second half of the eighteenth century. To do so, we will focus on the famous and controversial writer Helen Maria Williams. We will begin with her biography, since it was entwined with the major events of the day, and we will discuss how this child of an army officer rose from a typical girlhood to become a prominent revolutionary thinker in France, and, eventually, a French citizen. We will read selections from Helen Maria Williams and the Age of Revolution (2002), in which Deborah Kennedy explains Williams' involvement in French Revolutionary culture. The students will read here and elsewhere of how Williams was personally acquainted with Benjamin Franklin, Thomas Paine, and Mary Wollstonecraft, among others, and that she had great influence in the intellectual circle of English advocates of the Revolution. One of the first of her works that students will read is Letters from France, containing Many New Anecdotes Relative to the French Revolution, and the Present State of French Manners (1792). Seeing how Williams addresses Burke's Reflections in this work, students will then have the chance to explore Williams' poems and prose to see how her portrayal of sensibility and its proper role in society differs from the arguably "masculinized" sensibility of Burke. Readers of Williams' work saw her writing as explicitly feminine in its threat to society: this critical reaction will lead us to criticism like Terry Castle's The Female Thermometer: Eighteenth-Century Culture and the Invention of the Uncanny (1995), in which Castle proposes that for British culture the female body is a kind of physical incarnation of the 
new culture of commercial communication led to a strong demarcation between masculine and feminine models of appropriate emotion.

Finally, we will read one of Williams' last works, Letters on Events which have passed in France since the Restoration of 1815 (1819), in order to understand how a Revolutionary and champion of radical sensibility could come to believe that the restoration of the Bourbon monarchy was not a terrible occurrence. By ending the course with one famous intellectual woman's personal odyssey through the late eighteenth century and beyond, we hope to be able to both humanize and contextualize the traditional narrative of the Enlightenment. 
Works Cited

Barker-Benfield, G. J. The Culture of Sensibility: Sex and Society in Eighteenth-Century Britain. NY: Oxford UP, 1996. Print.

Burke, Edmund. Reflections on the Revolution in France. NY: Oxford UP, 2009. Print.

Byron, George Gordon, Lord. Childe Harold's Pilgrimage (excerpts). The Norton Anthology of English Literature. $9^{\text {th }}$ ed. Vol.D. Gen ed. Stephen Greenblatt. New York: Norton, 2012. 620-37. Print.

Castle, Terry. The Female Thermometer: Eighteenth-Century Culture and the Invention of the Uncanny. NY: Oxford UP, 2005.

Cowper, William. The Task. NY: Longman, 1995. Print.

De Staël, Germaine. "Letters on Rousseau." An Extraordinary Woman: Selected Writings of Germaine de Staël. Trans. Vivian Folkenfilk. New York: Columbia UP, 2000. 39-43. Print.

The Encyclopedia of Diderot \& d'Alembert Collaborative Translation Project. Ann Arbor: MPublishing, University of Michigan Library, 2011. Web. 16 May 2013. http://quod.lib.umich.edu/d/did/.

Franklin, Benjamin. Autobiography and Other Writings. Ed. Ormond Seavey. NY: Oxford UP, 2009. Print.

Gaustad, Edwin. Benjamin Franklin. NY: Oxford UP, 2006. Print.

Gray, Thomas. Selected Poems. NY: Bloomsbury, 1997. Print.

Isaacson, Walter. Benjamin Franklin: An American Life. NY: Simon and Schuster, 2004. Print.

Kennedy, Deborah. Helen Maria Williams and the Age of Revolution. Lewisburg, PA: Bucknell UP, 2002.

Paine, Thomas. Rights of Man, Common Sense, and Other Political Writings. NY: Oxford UP, 2009. Print.

Rousseau, Jean-Jacques. Politics and the Arts: Letter to M. d'Alembert on the Theatre. Trans. Allan Bloom. Ithaca, NY: Cornell UP, 1960. Print.

Voltaire. Candide or Optimism. Trans. Theo Cuffe. New York: Penguin, 2005. Print. 
Williams, Helen Maria. Letters Written in France. Ed. Neil Fraistat and Susan S. Lanser. Peterborough, Ontario: Broadview, 2001. Print.

Wordsworth, William. "Lines Composed a Few Miles above Tintern Abbey, on Revisiting the Banks of the Wye during a Tour, July 13, 1798." The Norton Anthology of English Literature. $9^{\text {th }}$ ed. Vol.D. Gen ed. Stephen Greenblatt. New York: Norton, 2012. 288-92. Print. 